\title{
REVIEW
}

\section{Settlement of benthic marine invertebrates}

\author{
Sebastián R. Rodríguez ${ }^{1}$, F. Patricio Ojeda ${ }^{1}$, Nibaldo C. Inestrosa ${ }^{2}$ \\ ${ }^{1}$ Departamento de Ecología, ${ }^{2}$ Departamento de Biología Celular y Molecular, Facultad de Ciencias Biológicas, \\ Pont. Universidad Católica de Chile, Casilla 114-D, Santiago, Chile
}

\begin{abstract}
Settlement and recruitment of benthic marine invertebrates are complex processes, determined by the interaction of biotic and abiotic factors which operate at different temporal and spatial scales. This review analyses the settlement process, attempting to integrate aspects related to different levels of organization (i.e. ecological-physiological-molecular). This is important because many factors that act at any of these levels and at different times can explain by themselves the patterns of settlement and/or recruitment of a large number of species. From an ecological perspective, progress has been made in the identification of causal factors of variations in larval availability for settlement. Many physical and ethological factors that act during settlement have, however, not received much attention. Likewise, since the great majority of settlement studies have been carried out at restricted spatial scales, fewer works consider different biological and physical factors acting at different scales sirnultaneously. Settlement patterns are frequently inferred from recruitment. In this sense, a density-independent action of post-settlement mortality has been considered as prerequisite for this type of inference. This has, however, recently been challenged on the basis that settler-recruit and mortality-settler density relationships change in time. At the physiological-molecular level, different settlement-inducing chemical cues have been identified. Those cues have, however, not yet been characterized to understand better the signal transduction mechanisms involved in larval responses. It is likely that the nervous system is involved. The use of artificial inducers would be useful in studying settlement induction, until more effective natural inducers are isolated and characterized. Although few studies have analysed the acquisition of competence, stages of larval development have been related to changes in protein patterns or enzymatic levels of the nervous system. An inopportune exposure of larvae to inducers may delay settlement and may even have a negative impact on growth and subsequent survival of juveniles.
\end{abstract}

\section{INTRODUCTION}

Most benthic marine invertebrates have pelagic larvae capable of dispersing over great distances (Thorson 1950). Traditional models have described the dynamics of many of these populations as closed systems, according to which the new individuals recruiting inside a given local population are offspring of females present in the same population (Karlson \& Levitan 1990). These models have assumed that once one of these populations is extinguished, the situation is irrevocable (May \& Oster 1976, Caswell 1978).

Roughgarden et al. (1985) recognized the problem of using closed models to describe population dynamics of benthic marine invertebrates with a great capacity of dispersion. Indeed, population models should consider the possibility of recruitment of individuals from other populations and that local extinctions could be followed by recolonization processes. Population models should describe the dynamics of open populations (e.g. Caswell 1978, Frogner 1980).

Roughgarden, Gaines \& Pacala (in Lewin 1986) argued that 'at some scale most ecological systems are open systems'; therefore the distinction between open and closed systems is somewhat irrelevant nowadays. In contrast, the importance of the source of recruits as 
a determining factor in important processes of marine systems and its influence on population structure and dynamics have been widely discussed (Underwood \& Fairweather 1989). Specifically, over the last years a new interest has arisen in the local variation of settlement and/or recruitment, and its consequences upon the distribution and abundance of marine species (Grosberg 1982, Keough \& Downes 1982, Keough 1983, 1984, Victor 1983, Underwood \& Denley 1984, Caffey 1985, Connell 1985, Gaines \& Roughgarden 1985, Butler 1986, Davis 1987, 1988, Bushek 1988, Fairweather 1988, Sutherland 1990, Minchinton \& Scheibling 1991). This new emphasis has been called 'supply-side ecology' (see Lewin 1986, Young 1987. Underwood \& Fairweather 1989). Therefore, it is indispensable to incorporate settlement and recruitment as variables in demographic models (Caffey 1985, Underwond \& Fairweather 1989).

Where settlement is dense, the predominant features of the community structure have been attributed to factors such as competition, predation and disturbance (Gaines \& Roughgarden 1985, Roughgarden et al. 1985, Lewin 1986, Sutherland \& Ortega 1986, Roughgarden et al. 1991), which correspond to the most important and extensively documented processes considered in traditional models (Underwood \& Denley 1984 . Underwood \& Fairweather 1989) and have been the basis of a group of models which have attempted to explain the most important ecological interactions and processes that determine the structure and dynamics of different marine assemblages (e.g. Dayton 1971, Menge 1976, Menge \& Sutherland 1976, Paine 1984, Connell 1985). Settlement and/or recruitment, in addition to the physical, chemical and biological factors and processes of the water column that affect them, would determine many patterns and would play an important role in communities with sparse settlement (e.g. Paine 1974, Keough 1984, Underwood \& Denley 1984, Gaines \& Roughgarden 1985, Roughgarden et al. 1985, 1991, Menge \& Sutherland 1987).

Population dynamics and community structure may also be affected by variations in the intensity of settlement of competing species or of species interacting through a predator-prey relationship (Connell 1985, Underwood \& Fairweather 1989, see also Fairweather 1988). Thus, changes in the larval source or recruitment levels of relevant species can define a scenario of ecological interactions (i.e. vary the intensity and/or the importance of one type of interaction or the other, both spatially and temporally; see Keough 1984, Menge \& Sutherland 1987), by determining a priori the participant's population sizes (Caffey 1985, see also Fairweather 1988).

The importance of settlement at the population and community levels and its biotechnological impact (set- tlement is one of the main stages in the cultivation of commercially important species) prompted us to carry out this analysis. This integration consists in the simultaneous or alternate consideration of ecological and physiological factors and processes. The objectives of the present review are: (1) to analyze the settlement process as a whole, considering ecological, physiological and biotechnological aspects, and (2) to suggest future lines of research. The analysis will follow the chronology of the settlement process.

\section{SETTLEMENT AND RECRUITMENT}

It is important to distinguish between settlement and recruitment. There are, however, numerous problems and conflicting views with respect to existing definitions of both processes, particularly those referring to settlement (see Keough \& Downes 1982, Coon et al. 1985, 1990a, b, Keough 1986, Davis 1987, 1988, Bonar et al. 1990. Harrold et al. 1991). In the case of benthic marine invertebrates with pelagic larvae, the term settlement should be used to ciescribe the passaye from a pelagic way of life to a benthic way of life. This passage implies not only a descent of the larva from the water column and a permanent residence on the substratum, but also a set of events and morphogenetic changes which allow the attached larvae to acquire features appropriate to its new life. These changes occur solely through metamorphosis.

Thus, we define settlement as a process beginning with the onset of a behavioral search for a suitable substratum and ending with metamorphosis. Two phases may be distinguished in this process: (1) a behavioral phase of searching for the suitable substratum, and (2) a phase of permanent residence or attachment to the substratum, which triggers metamorphosis and in which morphogenetic events take place. Although there are examples in which metamorphosis occurs before the attachment to the substratum (e.g. Paracentrotus; Fenaux \& Pedrotti 1988), they are rather uncommon. The recognition of these 2 phases in settlement renders this term more operational. This is important, particularly for those searching for chemical cues that may generate settlement responses in the larvae. In fact, the behavioral and morphogenetic responses may be triggered by different inducers (Inestrosa et al. 1988). Recruitment, on the other hand, implies the lapse of some period of time. The latter is variable and defined by the researcher (Roegner 1991). Hence, we consider recruits as newly settled individuals (i.e. settlers) that have survived to a specified size after their settlement (see also Keough \& Downes 1982 , Connell 1985, Butler 1986. Hurlbut 1991). This review is concerned with factors influencing settlement. 


\section{LARVAL AVAILABILITY}

Factors affecting pre-settlement can be as important as subsequent ones in the determination of distribution patterns of sessile and some mobile species (Denley \& Underwood 1979, Grosberg 1982, Watanabe 1984). For example, the availability of competent larvae for settlement influences the number of individuals recruiting within a population (Cameron \& Schroeter 1980, Connell 1985, Cameron 1986) and is subject to temporal as well as spatial variations. In brief, the most important phenomena that alter the abundance of larvae in the water column, and that are responsible for the temporal variability of settlement, can be associated to one of the following categories: (1) reproductive cycles of adult individuals (Davis 1989, Roughgarden et al. 1991), (2) patterns of winds (Barnes 1956, Hawkins \& Hartnoll 1982), currents and other hydrographic factors (Yoshioka 1982, Gaines et al. 1985), and (3) changes in rates of larval mortality (due to predation, or as the outcome of their longer retention in the plankton) (Thorson 1950, Hadfield 1963, Paine 1963, Loosanoff 1964, Mileikovsky 1974, Tegner \& Dayton 1981, Cowden et al. 1984, Grant \& Williamson 1985, Gaines \& Roughgarden 1987, Hart \& Scheibling 1988, Zimmerman \& Pechenik 1991).

Larval availability is also subject to spatial variations, mainly determined by the distribution of larvae in the water column. This larval distribution is responsible for spatial variability in settlement, at large and small scales, and has been attributed to factors similar to those already analysed as the cause of temporal variability (see Gaines et al. 1985), such as: (1) currents, wind patterns and topography (e.g. Underwood 1972 , Hawkins \& Hartnoll 1982); (2) regional differences in larval mortality (Lewis et al. 1982); (3) spatial differences in rates of predation (Mileikovsky 1974); and (4) larval behavior through the formation of aggregations in the water column (Keough 1983). In this context, the importance of local hydrographic processes and larval behavior in the distribution of larvae in the water column has been recently highlighted (Jackson 1986).

Even though temporal and spatial larval availability are important when dealing with larval production, we have only mentioned some of the most relevant factors affecting the abundance of larvae for settlement because a more comprehensive analysis of this subject is not directly pertinent to the topic of this review.

The settlement process requires not only that a larva be present at a site, but also that, once the larva is at the site, its spatial pattern at a small scale be determined both by the interaction of physical processes and biological responses and by the presence of chemical cues (Table 1). These processes and responses are discussed below.
Table 1. Examples of the main factors acting during the settlement response of benthic marine invertebrate larvae

\begin{tabular}{|ll|}
\hline Factors & \multicolumn{1}{c|}{ Examples } \\
\hline Biological & Larval behavior \\
& $\begin{array}{l}\text { Water flow velocity } \\
\text { Contour and chemistry of the } \\
\text { attachment substrate surface } \\
\text { Luminous intensity }\end{array}$ \\
$\begin{array}{c}\text { Chemical } \\
\text { Natural inducers }\end{array}$ & $\begin{array}{l}\text { Associated with conspecific } \\
\text { individuals }\end{array}$ \\
& $\begin{array}{l}\text { Associated with microbial films } \\
\text { Associated with prey species } \\
\text { Artificial inducers }\end{array}$ \\
& $\begin{array}{l}\text { Neurotransmitters } \\
\text { (e.g. GABA, catecholamines) } \\
\text { Neurotransmitter precursors } \\
\text { (e.g. choline) } \\
\text { Ions (e.g. potassium) }\end{array}$ \\
\hline
\end{tabular}

\section{SETTLEMENT}

Dividing the early life-history of marine organisms into a series of functional stages (e.g. dispersal, development, competence, settlement, metamorphosis, etc.) is an old idea (see Underwood 1979 for a review). The planktonic larval state can be divided into a period of pre-competence, in which growth and development occurs, and one of competence, in which development has been completed (Jablonski \& Lutz 1983). Acquisition of the ability to respond to the appropriate stimuli has usually been termed competence (Coon et al. 1990a). The physiological mechanisms by which larvae become competent are poorly understood, but some studies implicate the larval nervous system (Burke 1983, Hirata \& Hadfield 1986, Pechenik \& Heyman 1987).

Larval adaptations for a planktonic life are retained until an adequate stimulus is found for settlement (Burke 1983). The stimuli necessary for settlement involve a combination of factors including the speed of fluids and contours of the substratum surface (e.g. Sebens 1983a, Wethey 1986, Pawlik et al. 1991), luminosity and chemical cues (e.g. Morse 1991, see also Hadfield \& Pennington 1990). Increases in luminosity trigger the deposition of cyprid larvae and water currents can induce their active swimming and attachment to the substratum (Crisp 1955, Crisp \& Ritz 1973). A strong light-dependence can prevent settlement of larvae in crevices, as in larvae of the coral Alcyonium siderium (Sebens 1983a). In the absence of an appropriate stimulus, many larvae delay their settlement 
(Thorson 1950, Knight-Jones 1953, Jensen \& Morse 1984, Highsmith \& Emlet 1986, Coon et al. 1990a). Nonetheless, Highsmith \& Emlet (1986) showed that a delay of metamorphosis has negative consequences for growth and subsequent survival of juveniles of 2 species of irregular echinoids. The presence or absence of an appropriate stimulus for settlement can have a great impact on postmetamorphic events.

Larvae of different species have different degrees of dependence and specificity with respect to the inducers that trigger their settlement (Morse 1990). This dependence and specificity would be associated with a recognition of the inducer of the chemosensory type (Morse 1991). It is precisely this recognition that activates the genetically scheduled sequence of behavioral, anatomical and physiological processes which determine settlement (Morse 1990, see also Yool et al. 1986).

Although exogenous chemical cues have been studied, few natural inducers of settlement in invertebrates have been isolated and characterized (Kato et al. 1975 , Pawlik 1986, see also Morse 1990, Pawlik 1990). The importance given recently to chemical cues must not make us underestimate the role played by some physical factors or processes, or by larval behavior itself. In this sense, hydrodynamic processes and larval behavior (e.g. geotaxis or phototaxis) can be of great importance by allowing a larva to be close to the bottom at the time of its settlement (Jackson 1986, see also Coon et al. 1985). This closeness to the ocean bottom can be crucial, because, for many species, the chemical cues would be associated with the inducing substratum and direct contact with the larva would be necessary for any effect to be triggered (e.g. Knight-Jones 1953, Morse \& Morse 1984, Pawlik 1986, Raimondi 1988). In addition to chemical cues, the responses to the conditions of the water flow played an important role in the recruitment of the polychaete Phragmatopoma lapidosa californica (Pawlik et al. 1991). The larvae tumbled along the bottom in the presence of fast flow, whereas in slow flow they were observed swimming in the water column.

Physical factors such as contouring of the substratum (Crisp \& Barnes 1954, Crisp 1961) are used by barnacle larvae to select discontinuities. Wethey (1986) observed that up to $30 \%$ of barnacle larvae settled on identical localities on replicate surfaces of the same contour. Wethey pointed out that passive larval deposition (see also Hannan 1984, Banse 1986, Butman 1989, Pawlik \& Hadfield 1990) and active selection of microsites with low shear associated with discontinuities on the substratum could account for the settlement observed. It is possible that larvae search first for substrata where there is high shear (Crisp 1955) and, once in contact with them, select microsites with low shear which allow better survival (Crisp \& Barnes 1954, see also Wethey 1986). An alternative could be that passive deposition would determine the distribution of larvae at a large scale and that passive or active redistribution would determine the localized distribution, as has been proposed for infaunal organisms (Butman 1989). In turn, Carleton \& Sammarco (1987) found that the success of settlement in corals can be improved by increasing the structural complexity of the substratum through irregularities. They highlighted the importance of the angle of slope of the substratum and its protection and pointed out that the aggregated distribution pattern observed in these populations can be influenced, at least in part, by the physical characteristics of the substratum. The importance of the heterogeneity of macro- and microsites in the process of selecting a substratum has also been shown by Le Tourneux \& Bourget (1988) and Chabot \& Bourget (1988). The chemistry of the surface during settlement (e.g. wettability) is an important factor in settlement of barnacles and bryozoan (Maki et al. 1989, Roberts et al. 1991). These studies indicate that many factors other than chemical cues have to be considered in any analysis of settlement.

\section{NATURAL INDUCERS}

Many settlement-inducing chernical cues have been discovered from observations of larval settlement on different natural substrata (see Rodríguez et al. 1992). These inducers originate from or are associated with various sources and have great ecological importance. These sources are of 3 main types: (1) conspecific individuals (Highsmith 1982, Burke 1984, Jensen \& Morse 1984, Pawlik 1986), (2) microbial films (Cameron \& Hinegardner 1974, Kirchman et al. 1982, Morse et al. 1984, Maki et al. 1989, Bonar et al. 1990, Pearce \& Scheibling 1991), and (3) prey species (Barnes \& Gonor 1973, Morse et al. 1979, Morse \& Morse 1984, Todd 1985, Barlow 1990, Hadfield \& Pennington 1990). Although a great majority of the known inducers can be included in one of these categories, they are not exclusive.

\section{Inducers associated with conspecifics}

Settlement induced by conspecific adults has been described in several benthic marine invertebrates, including polychaetes (Jensen \& Morse 1984, Pawlik 1986). sipunculids (Hadfield 1986), echinoids (Highsmith 1982), molluscs (Seki \& Kan-no 1981, Slattery 1992), bamacles (Knight-Jones 1953, Raimondi 1988, 1991) and oysters (Hidu et al. 1978). 
The existence of larval inducers associated with conspecific adults has great ecological importance, because the induction of settlement by conspecifics can account for the aggregated distributions of many benthic marine invertebrates. This is a mechanism which not only increases the probability of fertilization of gametes of individuals which release their gametes into the sea (Pearse \& Arch 1969, Russo 1979, Pawlik 1986) or which have internal fertilization (e.g. barnacles), but also acts as an effective defense mechanism (Garnick 1978, Bernstein et al. 1981, Pawlik 1986).

For example, settlement of abalone larvae is stimulated by the mucus produced and secreted by adult and juvenile individuals (Seki \& Kan-no 1981, Slattery 1992). A growth-associated factor has recently been identified in the large muscular foot of the mollusc Concholepas concholepas. Such a factor stimulates cell proliferation, binds to heparin-agarose resins, requires sulfation activity in the responding cell for activity and apparently induces cellular differentiation (Cantillana \& Inestrosa 1993) Therefore, it is possible that the mucus of adult and juvenile abalones contains heparin-binding growth factors which could be responsible for triggering larval settlement.

The best example of settlement induced by conspecifics is that of the sabellid polychaete Phragmatopoma lapidosa californica. Larvae settle as a response to free fatty acids (e.g. palmitoleic and linoleic acids) isolated from the sand and cement matrix of the tubes of adults (Pawlik 1986). This response is highly species-specific and restricted to the genus Phragmatopoma. Nonetheless, Pawlik did not rule out the possibility of hydrophilic molecules being involved in the induction. It has been postulated, as an alternative hypothesis, that a polymeric protein (rich in residues of dihydroxyphenylalanine) was the actual agent responsible (Jensen \& Morse 1990).

Highsmith (1982) demonstrated that a small peptide of low molecular mass ( $<10000)$ produced by adults of the irregular echinoid Dendraster excentricus and sequestered by some component of the sand in which they were buried was the settlement-inducing chemical cue (see Burke 1984 for the same species, and Pearce \& Scheibling 1990b for the irregular echinoid Echinarachnius parma). In this context, settlement would preferentially occur within the areas inhabited by conspecific adults, generating an aggregated pattern of distribution of the population. This phenomenon is important not only because this larva-adult interaction generates an ecological pattern, but also because it allows the larva to avoid its predators, which tend to occur in areas where adults of this detritivorous species are absent (Highsmith 1982).

Studies of barnacles have also stressed the fact that the presence of conspecific individuals can have great influence on larval settlement through chemical cues. Larvae of the barnacle Chthamalus aniposoma settle within the range of adult distribution (Raimondi 1991). Larval settlement in adult patches transplanted away from the limits of their distribution indicates that induction of settlement was somehow associated with the presence of conspecific adults. Raimondi, however, did not rule out the possibility that other unknown factors also limited settlement within the vertical range of distribution of adults

\section{Inducers associated with microbial films}

Microbial films are important in the settlement of many marine invertebrate pelagic larvae. Settlement is induced by films of diatoms and cyanobacteria (e.g. Morse et al. 1984) and by bacterial films (e.g. Kirchman et al. 1982 for polychaetes, Cameron \& Hinegardner 1974 for sea urchins, Maki et al. 1988 for barnacles, Maki et al. 1989 for bryozoans and Bonar et al. 1990 for oysters). In the latter case the response is quite specific and is generated by the presence of extracellular polysaccharides or glycoproteins attached to the bacterial wall (Kirchman et al. 1982, Hadfield 1986) or soluble compounds released by these films (Bonar et al. 1990). Bonar et al. (1990) observed that while the former favors metamorphosis of oyster larvae of the genus Crassostrea, the soluble compound (molecular weight $<300$ Da; see Fitt et al. 1990) induces searching behavior on the substratum (see also Coon et al. 1990b). Although a greater percentage of settlement (or an increase in the inductive potential) has been observed in the presence of older bacterial films (see also Maki et al. 1989 for bryozoans, Fitt et al. 1990 for oysters, and Pearce \& Scheibling 1991 for sea urchins), cases have also been described in which an inhibitory effect has been observed (Maki et al. 1988). The inductive or inhibitory effect of a film may be partly determined by its specific composition (Maki et al. 1989). Antibiotics that inhibit bacterial metabolism do not inhibit the settlement response, suggesting that a metabolically active film is not necessary for the response (Kirchman et al. 1982).

Besides the soluble inducers derived from bacterial films, ammonia, which is secreted by most bacteria and marine animals, is related to the searching behavior of larvae of the genus Crassostrea (Bonar et al. 1990). This implies that in areas of high biological activity, regardless of the presence or absence of bacterial films, $\mathrm{NH}_{3}$ could reach sufficiently high levels to induce the search behavior (Coon et al. 1990b). Another compound which induces search behavior in oyster larvae is L- $\beta$-3,4-dihydroxyphenylalanine (L-DOPA) (Coon et al. $1990 \mathrm{a}, \mathrm{b}$ ). This compound could originate in bacte- 
rial films or from conspecific individuals (Coon et al. 1985). The inducing concentrations of this compound would be found only in the vicinity of the source. If the substratum is appropriate, the larva would cement by itself and endogenous molecules similar in their action to epinephrine and norepinephrine would induce the onset of metamorphosis (Coon et al. 1985). $\mathrm{NH}_{3}$ and LDOPA differ in the amount of time needed for induction and probably also in the mechanisms by which they are transduced (Bonar et al. 1990, Coon et al. 1990b).

\section{Inducers associated with prey species}

In some larvae, settlement is induced by potential prey species of juveniles or adults. Many herbivorous species are induced to settle by crustose algae on which they feed. These include abalone (Morse \& Morse 1984, Morse 1990), chitons (Barnes \& Gonor 1973), limpets (Steneck 1982) and sea urchins (Cameron \& Hinegardner 1974, Rowley 1989, Pearce \& schelbing i990a, 1991j.

Inducing chemicals would be available on the surface of the encrusting algae and would possibly be released when epithelial cells are grazed (see Morse \& Morse 1984). In cell-free extracts, the inducer appears in association with phycobiliproteins (Morse et al. 1979, Morse \& Morse 1984, see also Morse et al. 1984). The inducer is an oligopeptide which mimics the action of $\gamma$-aminobutyric acid (GABA) by binding to its specific receptors (see Morse 1990). Induction of settlement by larvae of the sea urchin Strongylocentrotus purpuratus has been observed by the same partially purified fraction of the peptide extracted from the wall of crustose coralline algae (Rowley 1989).

Crustose coralline algae are also substrata for settlement of coral larvae (Sebens 1983a, b). Morse (1991) reported that larvae of the coral Agaricia humilis settle in response to a sulfating polysaccharide in the wall of the alga. The mechanism of transduction would, however, be different from that in abalone. Morse pointed out that recognition in these organisms could be mediated by known receptors such as lectins, which are important in the control of cellular differentiation.

Foliose algae also have inducing activities. Inducing molecules for abalone larvae occur in extracts of foliose red algae, including species of Laurencia, Gigartina and Porphyra, even though they are not present on the surface of any of them and the larvae do not respond to intact fronds of these species (Morse \& Morse 1984). Larvae of the chiton Ischnochiton heathiana metamorphose on foliose algae of the genus Ulva (Barnes \& Gonor 1973). A similar phenomenon has been described for the hydroid Coryne uchidai in which the epoxid of $\gamma$-tocotrienol present in the red alga Sargassum tortile is the agent inducing settlement (Kato et al. 1975).

Some carnivorous species, particularly nudibranchs, also settle in response to their prey. For example, Onchidoris bilamellata only metamorphoses in the presence of its prey, newly settled barnacles (Todd 1985). The nudibranch Phestilla sibogae feeds exclusively on the coral Porites compressa, the only known source of an inducer (Pennington \& Hadfield 1989, Hadfield \& Pennington 1990). The inducer is a small (<500 Da), polar, water-soluble molecule, which acts at small concentrations $(<10 \mathrm{nM})$. The larvae of $P$. sibogae respond to dissolved substances and do not need to establish direct contact with the substratum (Hadfield 1986, Hadfield \& Pennington 1990). No compound induces metamorphosis in $P$. sibogae as quickly and efficiently as the inducer associated with its prey species.

Potential predators may also produce inducing signals. Gastropods of the genus Acanthina are an excellent settlement-inducing cue for larvae of the barnacle Chthamalus anisopoma, despite heing an important predator of that species, probably because the whelk is a good index of the limits of vertical distribution of adult barnacles (Raimondi 1988).

Inhibitors of settlement occur. Toxic and non-toxic natural products of the ascidian Eudistoma olivaceum inhibit the settlement of larvae of the bryozoan Bugula neritina (Davis \& Wright 1990). The settlement of larvae of the colonial ascidian Podoclavella molluccensis is inhibited by natural products released by or associated with the surface of sponges (Davis et al. 1991). The presence of oysters inhibits the settlement of barnacles (Bushek 1988). In this sense, settlement and subsequent recruitment could be the outcome of rejection responses to negative signals rather than the result of lack of positive responses to favorable signals (Woodin 1991).

\section{ARTIFICIAL INDUCERS AND MECHANISMS OF SIGNAL TRANSDUCTION}

Besides the proteins associated with conspecifics, polysaccharides from bacterial films, and polypeptides present in prey species, other chemical substances trigger settlement in marine invertebrate larvae. Their study permits a better understanding of the mechanisms involved in the larval response. In many species, chemical cues associated with the substratum are substances which mimic the action of neurotransmitters. This implies the operation of neuronal receptors in the initial process which triggers settlement (Baloun \& Morse 1984, Yool et al. 1986) 
The chemical structure of most of these inducers suggests possible mechanisms involved in the transduction of signals triggering metamorphosis, as discussed below.

\section{Choline derivatives}

Choline is the precursor of the neurotransmitter acetylcholine and of phosphatidylcholine, an important component of biological membranes. Succinylcholine and choline induce settlement in the gastropods Phestilla sibogae (Hirata \& Hadfield 1986) and Ilyanassa obsoleta and incomplete settlement in the polychaete Phragmatopoma lapidosa californica (see Pawlik 1990). In the case of $P$. sibogae, the receptors for choline and for the natural inducer would be different, because, in experiments in which both substances were present, neither competition for receptors nor habituation of the pre-competent larvae to choline derivatives has been observed (Hirata \& Hadfield 1986). Apparently choline derivatives do not act on external receptors, but directly activate the nervous system, as has been suggested for P. lapidosa californica (Pawlik 1990). This is because the larvae actively take up large amounts of choline from the external medium (Hadfield \& Pennington 1990). Choline could be involved in induction of settlement in several ways: (1) by acting directly on the cholinergic receptors; (2) by participating as precursors in acetylcholine biosynthesis; or (3) by stimulating synthesis and release of catecholamines as neurotransmitters (Hirata \& Hadfield 1986, Hadfield \& Pennington 1990).

\section{L-DOPA and catecholamines}

L-DOPA and the catecholamines (dopamine, adrenaline and noradrenaline) are tyrosine derivatives with different biological functions, such as hormones, neurotransmitters, pigments and adhesive and structural proteins. Tyrosine derivatives induce settlement in species of bivalves such as Crassostrea virginica and Mytilus edulis (Pawlik 1990). L-DOPA induces searching behavior in Crassostrea gigas, whereas adrenaline and noradrenaline only induce metamorphosis without previous searching (Bonar et al, 1990, Coon et al. 1990a). Bonar et al. (1990) proposed that L-DOPA from the external medium is incorporated into the larva and transformed into dopamine, which then acts on dopaminergic receptors. This observation, supported by the fact that these oyster species have a delayed response to catecholamines with respect to dopaminergic stimulation, suggests that catecholamines activate an endogenous sequence of metamorphic events
(Coon et al. 1985, Bonar et al. 1990, Pawlik 1990). The endogenous levels of noradrenaline change greatly during larval development, doubling just before the acquisition of metamorphic competence (Bonar et al. 1990). Pharmacological analyses have shown that these catecholamines act on adrenergic receptors of the $\alpha-1$ type, which leads to the hypothesis that the second inositol-phosphate messenger mediated by calcium operates in the transduction of the adrenergic signal. This, however, has not been clearly demonstrated (Bonar et al. 1990).

L-DOPA, adrenaline and noradrenaline have inductive effects in other molluscs. Larvae of the bivalves Mytilus edulis and Pecten maximus respond, respectively, to L-DOPA and to L-DOPA and adrenaline (see Pawlik 1990). Larvae of the gastropod Ilyanassa obsoleta respond to dopamine (Levantine \& Bonar 1986). Larvae of polychaetes and echinoids respond to molecules derived from tyrosine. The polychaete Phragamtopoma lapidosa californica is induced to settle with the same intensity by L-DOPA and by its isomer D-DOPA (Pawlik 1990). Only dopamine induces metamorphic responses in the larvae of the irregular echinoid Dendraster excentricus (Burke 1983).

These observations are compatible with the hypothesis that dopamine, or one of its derivatives, acts as the chemical messenger during the induction of metamorphosis. Burke (1983) indicated that this endogenous chemical cue could act directly upon larval tissues, or indirectly by inducing the release of additional substances which stimulate the tissues that contain the effectors of metamorphosis. This hypothesis is consistent with the fact that reserpine (a substance that depletes catecholamines in vertebrates tissues) interferes with and inhibits metamorphosis (Burke 1983).

\section{Other aminoacid derivatives}

GABA is a product of glutamic acid decarboxylation and acts as an inhibitory neurotransmitter. It induces hyperpolarization of post-synaptic membranes by means of an increase in the membrane permeability to chloride ions. In some cases, however, it actives a depolarizing flux of chloride (Kuffler et al. 1984). GABA and analogous molecules (e.g. $\gamma$-hydroxybutyric acid, $\gamma$-amino-n-valeric acid, $\varepsilon$-amino-n-caproic acid, muscimol, gabuline and baclofen) are powerful inducers of settlement in the gastropod Haliotis rufescens (Morse et al. 1979, Trapido-Rosenthal \& Morse 1986a, b, Morse 1991). This reflects the stereochemical specificity of the larval receptors of this mollusc for these compounds (Morse \& Morse 1984, Trapido-Rosenthal \& Morse $1986 \mathrm{a}, \mathrm{b})$. Induction of metamorphosis by GABA would depend on the depolarization of GABA-sensi- 
tive cells exposed to the external medium and would be mediated by a net depolarizing chloride efflux or another anion (Baloun \& Morse 1984). Induction by GABA is inhibited by high external concentrations of chloride or a blocker of potassium channels (e.g. tetraethylammonium). This suggests that the chloride efflux plays an important role in the transduction of the GABA signal (Baloun \& Morse 1984).

An increase in calcium concentration inhibits induction by GABA, probably by means of the activation of potassium channels regulated by calcium, producing a net hyperpolarizing flux (Baloun \& Morse 1984). These authors have observed that a decrease in external potassium concentration inhibits induction by GABA, which could be due to hyperpolarization and which would antagonize the depolarization mediated by GABA. The activation of anionic channels would depend on enzymes phosphorylated by protein kinases A, which would, in turn, be activated by cAMP (Morse et al. 1980, Trapido-Rosenthal \& Morse 1986b). The levels of the latter would be increased by the activation of the adenylate cyclase through the binding of the exogenous ligand (inducer) io ihe recepior (Morse 1991).

The sensibility of the morphogenetic pathway in Haliotis rufescens would be controlled by 2 regulatory pathways. One would be related to a facilitation phenomenon (i.e. up-regulation.) of the settlement response, determined by compounds which act in a concentration-dependent manner and which would not have to be present simultaneously with the inducer to generate the effect (Trapido-Rosenthal \& Morse 1986a).

In this context, Haliotis rufescens larvae exhibit an amplification of sensitivity at small concentrations of the inducer, as a response to small concentrations of lysine and related aminoacids (Morse 1991). The larval receptor activated by lysine (which is different from the GABA receptor; see Trapido-Rosenthal \& Morse 1986a) would activate a $G$ protein, which would act on a phospholipase $\mathrm{C}$ associated with the membrane. The latter would hydrolyze a phosphatidylinositol anchored to the membrane, releasing diacylglycerol and inositol triphosphate $\left(\mathrm{IP}_{3}\right)$. The former would activate a

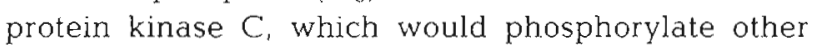
proteins involved in the amplification process (Morse 1991). The outcome of the interaction of both pathways would greatly increase the sensitivity of the larva. This would presumably allow settlement responses in suitable areas in the presence of small concentrations of the inducer associated with the algal surface (Morse 1990). It would even enhance settlement in coastal areas rich in nutrients (aminoacids are contained in dissolved organic materials.

The other regulatory pathway would be related to a habituation process of the settlement receptors (i.e. down-regulation), a phenomenon determined by a reduction in the number of these receptors as the outcome of the early exposure of the larva to the inducer (i.e. pre-competent larva) (Trapido-Rosenthal \& Morse 1986a). Trapido-Rosenthal \& Morse (1986b) demonstrated that, during larval desensitization, the postreceptor pathways of transduction (e.g. CAMP and excitatory depolarization) would remain intact

Induction by GABA-occurs in other molluscan species, namely the gastropods Trochus spp., Mopalia muscosa and Tonicella lineata (complete metamorphosis), Conus spp., Aplysia spp., Teredo spp. (incomplete metamorphosis) and the chiton Katharina tunicata (settlement without metamorphosis) (Morse et al. 1979, Morse et al. 1984, Pawlik 1990). Induction has also been observed in the sea urchin Strongylocentrotus droebachiensis (Pearce \& Scheibling 1990a). On the other hand, no effect at all has been observed in the polychaete Phragmatopoma lapidosa californica (Pawlik 1990), the cnidarian Alcyonium siderium (Sebens 1983b), the echinoid Dendraster excentricus (Burke 1983) or the molluscs Phestilla sibogae (Hadfield 1984), Crassosirea gigas (Coon et ai. i9985) and Crepiduia fornicata (Pechenik \& Heyman 1987). The variable results encountered by diverse authors in the response of abalone larvae to GABA (from narcotic effects up to complete settlement) explain why it has not been generally used as an inducer of settlement in the cultivation of this commercially important gastropod (see Pawlik 1990). Additional inductive pathways which utilize mucus or some associated component to trigger larval settlement are probably present in molluscs. In fact, recent evidence indicates that high larval settlement rates of Haliotis rufescens occur on substrates of conspecific mucus containing some unknown inductive cue (Slattery 1992). In this context, it is interesting to mention that a heparin-binding growth factor has been identified in foot extracts of the prosobranch mollusc Concholepas concholepas (Cantillana \& Inestrosa 1993)

\section{Induction by ions}

The sensory bases of induction suggest that the nervous system is involved in the onset of metamorphosis (Burke 1983, Yool et al. 1986). The conduction of electric impulses in nervous tissues depends on the maintenance of an electrical potential through the cell membrane, which is a function of the permeability of the membrane to potassium, sodium and chloride (Kuffler et al. 1984, Barlow 1990). Hence it is of interest to analyze the effects on settlement of ions and compounds that affect ionic transport through membranes.

Larvae of a number of species undergo metamorphosis in response to large concentrations of potassium 
ions, e.g. the molluscs Haliotis rufescens, Phestilla sibogae, Astraea undosa (Yool et al. 1986), Crepidula fornicata (Pechenik \& Heyman 1987). Adalaria proxima (Todd et al. 1991), Concholepas concholepas (Inestrosa et al. 1992) and the polychaete Phragmatopoma lapidosa californica (Yool et al. 1986). Potassium may act by means of the direct depolarization of excitable cells involved in the perception of inductive stimuli and, as with GABA, their action would depend on their concentration and exposure time (Baloun \& Morse 1984).

Baloun \& Morse (1984) showed that tetraethylammonium (a compound that selectively blocks potassium channels dependent on voltage in neuronal and muscular cells) inhibits metamorphosis in the abalone Haliotis rufescens in response to potassium, but not in response to GABA. Larvae of Phestilla sibogae and Phragmatoma lapidosa californica are, however, insensitive to this compound (Yool et al. 1986). Yool et al. (1986) suggested that, in these species, potassium could act through different channels from those suggested for potassium-induced metamorphosis in abalone larvae.

The induction of settlement by potassium triggers metamorphosis of a large number of species, making it a useful agent for the cultivation of commercially important marine invertebrates (but see Rittschof et al. 1986). The use of GABA, L-DOPA and other inducers has been replaced by use of potassium ions which, at up to $20 \mathrm{mM}$, depolarize the epithelial membrane, triggering metamorphosis (Yool et al. 1986, Pechenik \& Heyman 1987, Inestrosa et al. 1992).

Calcium flux has also been implicated in the modulation or transduction of morphogenetic signals in Phragmatopoma californica (Yool et al. 1986), where attachment to the substratum occurs when chloride in the medium is replaced with substitute anions like $\mathrm{Br}^{-}, \mathrm{SO}_{4}{ }^{2-}, \mathrm{NO}^{3-}$, acetate, isothionate or propionate. Settlement has also been induced in Crepidula fornicata by $\mathrm{Rb}^{+}$and $\mathrm{Cs}^{+}$(Pechenik \& Heyman 1987).

\section{AFTER SETTLEMENT}

Recently, particular interest has focused on the settler-recruit relationship (McGuinness \& Davis 1989). This is mostly due to the difficulty in measuring in situ the settlement of competent larvae, which, besides being small, vary temporally and spatially in their availability (Keough \& Downes 1982, Connell 1985, Hadfield 1986, Keough 1986, Davis 1988, McGuiness \& Davis 1989, Harrold et al. 1991). Considering this, the question arises whether it is possible to infer settlement rates starting from recruitment, and, if so, what conditions would be involved. A key subject in this area is the determination of the mechanism of action of mortality after settlement - that is, whether its action is density-dependent or density-independent. As summarized by Hurlbut (1991), usually when the settlement rate is low, juvenile mortality is density-independent; when it is high, mortality is density-dependent.

One way of determining whether settlement density affects the subsequent mortality of settlers has been to study the mortality-settler density relationship (Roegner 1991). Between these 2 variables, 3 fundamental relations have been described using linear regression models (see Roegner 1991): (1) a relation with a slope $>0$ which describes density-dependent mortality; (2) one with a slope $=0$ which describes densityindependent mortality; and (3) one with a slope <0 which describes an inverse density-dependent mortality (i.e. the greater the settler density, the greater the survival).

Density-independent mortality has been considered as a prerequisite for accurate estimation of settlement patterns from recruitment (Connell 1985, Davis 1988, McGuiness \& Davis 1989, Hughes 1990, Sutherland 1990). Density-independent mortality exists for newly settled juveniles in a number of benthic marine invertebrate groups, e.g. barnacles (Sutherland 1990), ascidians (Davis 1987), bryozoans (Hughes 1990) and sea urchins (Karlson \& Levitan 1990; this study was conducted indirectly through the use of data on size frequency). Notwithstanding, some works report the lack of a settler-recruit relationship (Keough \& Downes 1982) or of a clear and consistent trend between settler density and subsequent mortality (Keough 1986), or have simply found density-dependency (McShane 1991).

The importance of post-settlement mortality (and mobility in the case of mobile species) in recruitment, and hence in structure, dynamics and regulation of populations, has been emphasized by many authors (Keough \& Downes 1982, Connell 1985, Davis 1987, Hurlbut 1991, Ojeda \& Dearborn 1991, Watanabe \& Harrold 1991, Woodin 1991). Although numerous physical and biological factors that act subsequently to settlement may be important in the determination of recruitment patterns, a more comprehensive analysis of this subject is not directly pertinent to the topic of this review.

\section{CONCLUSIONS AND SUGGESTIONS FOR FUTURE RESEARCH}

Settlement is a complex process in which several physical, chemical and biological factors interact. For settlement to occur at any site the following are necessary: (1) temporal and spatial availability of larvae; and 
(2) selection and attachment to the substratum with subsequent metamorphosis, which depends on physical and chemical cues and on the larval behavior and response.

Only when settlement is well understood will it be possible to incorporate settlement into specific population models and therefore have a better understanding of temporal and spatial variations. For these reasons, it is esssential to analyse settlement from the widest possible perspective, attempting to integrate aspects of different disciplines (e.g. ecology and physiology).

It is important to clarify the concepts used in order to unify criteria. It is indispensable that these concepts be operational, so that they may be really useful. In this context, we define settlement as a process of change from a pelagic to a benthic way of life, including 2 phases: (1) one of searching behavior for an appropriate site, (2) another of permanent contact with or attachment to the substratum which triggers metamorphosis.

A number of ecological factors and processes are involved in the generation of settlement. Physical factors such as surtace contour, heterogeneity of substratum and microsites of low shear and larval behavior can be critical for the selection of settlement sites. Larvae, for instance, may simply tumble along the bottom (Pawlik et al. 1991) or vary their phototaxic response according to luminous intensity (Young \& Chia 1982). Many of these processes have, however, not received sufficient attention, particularly in relation to their interaction with inductive chemical cues. For example, larvae search for suitable sites for settlement at several different scales, with consequently different biological and physical influences (Le Tourneux \& Bourget 1988). Chabot \& Bourget (1988) found that selection by larvae of the barnacle Semibalanus balanoides at a large scale was related to the heterogeneity of the substratum. In contrast, at a smaller scale settlement was influenced by conspecific individuals. Butman (1989) indicated that while passive deposition of larvae could determine their distribution at a large spatial scale, the outcome at a small scale could be the consequence of a subsequent redistribution (passive or active). Such studies are scarce; most analyses of settlement have been at restricted spatial. and geographic scales.

Together with intensifying the study of physical and ethological factors, it will be necessary to analyse more accurately the identity of agents responsible for the induction of settlement. Johnson et al. (1991a, b) suggested that the compounds inducing settlement of a number of species - which historically have been associated with the surface of crustose coralline algae (Morse \& Morse 1984, Morse et al. 1984) - likely would not be produced by the algae, but by bacteria associated with them. This new hypothesis is interesting and requires more meticulous studies on the identity of the inducers of settlement.

A recurrent subject in the study of settlement is related to the inference of settlement patterns from recruitment patterns. Density-independent mortality after settlement has been considered as a prerequisite for this kind of estimation, but this has been challenged by Holm (1990). Holm pointed out that recruitment could reflect settlement in spite of densitydependent mortality, especially if settlement densities were small. Roegner (1991) indicated that, with oysters, even density-independent mortality did not allow the estimation of settlers from recruits with reasonable accuracy. That was the case because mortality rate between censuses (i.e. in time) was not constant. Thus, simple back estimates of settlers from recruits using linear regressions are not precise enough to be useful (Roegner 1991). Roegner's study places the issue at the starting point, and further investigations would be needed in the attempt to infer settlement patterns from recruitment. Notwithstanding, development of refined techniques and methodologies allowing direct examination of the settlement process (i.e. metamorphosis) will be more useful than retrospective estimations from recruitment.

From a physiological-molecular perspective, chemical cues have been widely considered in studies of settlement. Few natural inducers have, however, been identified, isolated and characterized (Pawlik 1986, 1990). Hadfield (1984) found no artificial inducer more rapid and efficient in action than that derived from the prey species of the nudibranch Phestilla sibogae. This suggests that future research should focus on features of the natural habitat. Inducers of settlement are more likely to be found among natural cues. Furthermore, these are the best tools for studying mechanisms of transduction and larval response. This is especially interesting because transduction is not well understood, although it is known that the generation of nervous impulses, and hence the nervous system, would be involved. Nonetheless, the use of artificial inducers is and will remain a useful tool for the study of settlement, particularly in the cultivation of commercially important species, until more effective natural inducers are discovered and isolated (Johnson et al. 1991a). Similarly, identification of these inducers could, in many cases, facilitate the search for signals in nature, especially through the knowledge of their physicochemical structure.

The specificity of the inducer and a high dependency of the larva to it may also be very important. In some cases, knowledge of specificity could allow better prediction of population and/or community patterns. Thus, determining patterns of distribution of settlement-inducing substrata and/or the differential con- 
centrations of inducers in the field would enable settlement patterns to be predicted. The problem is that to determine the specificity of an inducer it is necessary to know and study its specific physico-chemical structure (e.g. aminoacid sequence in the case of peptides, or active domains in the case of proteins) and the nature of the inducers in related species (Hadfield 1986). This has not yet been done, although there is some evidence of species-specific responses to inducing substrata, as in the case of different coral species which respond to different species of coralline algae (Morse 1991).

Finally, the knowledge of settlement-inducing cues at different taxonomic levels could be a useful tool in the study of phylogenetic relations between taxa and, in turn, could help to understand the origin and evolution of settlement at the receptor-signal level.

Another interesting aspect of settlement that should be studied in an ecological context is the phenomenon of habituation of the receptors to inducers (determined by a decrease of their number in the corresponding chemosensorial cells) as a consequence of early or repeated exposure to the cue (Trapido-Rosenthal \& Morse 1986a, Morse 1991). For species that have larvae with a short period of pelagic life (e.g. abalone), this phenomenon would be an excellent ecological mechanism for improving larval dispersal and preventing immediate settlement of larvae near their parents, thus avoiding subsequent competition for space and food.

From a biotechnological perspective, ignoring the timing of the acquisition of competence could result in a premature exposure of pre-competent larvae to the inducer, resulting in a delay in settlement. In the same way, a delay in the exposure of competent larvae to the inducer could have a negative impact on growth and subsequent survival of juveniles, as in an irregular echinoid (Highsmith \& Emlet 1986). The relationship between stages of larval development and changes in protein patterns, second messengers, or enzymatic levels of the nervous system has not been sufficiently examined, but one example is the study of Inestrosa et al. (1990). Further studies in this direction are necessary to determine the onset of competence, which is paramount for rearing larvae of commercially important species, but would also allow investigation of the intrinsic larval changes associated with settlement.

Recently, an interesting and timely study into the biochemical changes accompanying metamorphosis in the mollusc Concholepas concholepas has been presented (Inestrosa et al. 1993). Molluscan metamorphosis is accompanied by several molecular changes including a modification in the pattern of protein synthesis, an increase in heparin-binding proteins (i.e. growth factors), a decrease in the larval levels of the secondary messenger cAMP and the appearance of a new form of the neurotransmitter-related enzyme acetylcholinesterase (Inestrosa et al. 1993). A further understanding of the specific molecular mechanisms that regulate these processes will undoubtedly establish an experimental framework to determine the environmental signals that control larval settlement, and consequently population recruitment. Therefore, the application of molecular technologies to ecologically oriented questions is an important new area of research to consider.

Another important point is the possible existence of inhibitory factors of the settlement process. In this regard, Woodin (1991) postulated that a rejection of negative or inhibitory cues, rather than a positive response to inducing signals, could be responsible for many patterns of settlement and recruitment observed in nature. From an ecological viewpoint, inhibition of settlement would be of vital importance, especially in sessile species which have no other mechanism for avoiding epibionts (Davis et al. 1989). On the other hand, isolation and characterization at the molecular level of inhibitory substances from these species could allow identification of anti-fouling substances, which are indispensable on the surface of structures such as docks and boats.

Settlement and recruitment are the initial processes determining the structure of populations of many species. Although they have long concerned biologists, they have received great attention only in recent years. Much progress has been made in the study of settlement processes. As shown here, synthesis of the findings of these studies reveals new areas for future work. A complete analysis of larval settlement depends on the future integration of biochemical, physiological, morphological and behavioural studies in an ecological context.

Acknowledgements. This work was supported by FONDECYT Grants $0753 / 91$ to F.P.O. and $3502 / 89$ to N.C.I. We sincerely thank constructive criticisms by Dr J. M. Lawrence on an earlier draft, and Dr A. J. Underwood for helpful comments and suggestions that greatly improved this manuscript. S.R.R is presently Becario Residente en Investigación (DIUC) at the Depto. Biologia Celular \& Molecular

\section{LITERATURE CITED}

Baloun, A. J., Morse, D. E. (1984). Ionic control of settlement and metamorphosis in larval Haliotis rufescens (Gastropoda). Biol. Bull. 167: 124-138

Banse, K. (1986). Vertical distribution and horizontal transport of planktonic larvae of echinoderms and benthic polychaetes in an open coastal sea. Bull. mar. Sci. 39: 162-175

Barlow, L. A. (1990). Electrophysiological and behavioral responses of larvae of the red abalone (Haliotis rufescens) to 
settlement-inducing substances. Bull. mar. Sci. 46: $537-554$

Barnes, H. (1956). Balanus balanoides (L.) in the Firth of Cycle: the development and annual variation in the larval population and the causative factors. J. Anim. Ecol. 25: $72-84$

Barnes, J. R., Gonor, J. J. (1973). The larval settling response of the lined chiton Tonicella lineata. Mar. Biol. 20: 259-264

Bernstein, B. B., Williams, B. E., Mann, K. H. (1981). The role of behavioral responses to predators in modifying urchins' (Strongylocentrotus droebachiensis) destructive grazing and seasonal foraging patterns. Mar. Biol. 63: 39-49

Bonar, D. B., Coon, S. L., Walch, M., Weiner, R. M., Fitt, W (1990). Control of oyster settlement and metamorphosis by endogenous and exogenous chemical cues. Bull. mar. Sci. 46: $484-498$

Burke, R. D. (1983). Neural control of metamorphosis in Dendraster excentricus. Biol. Bull. 164: 176-188

Burke, R. D. (1984). Pheromonal control of metamorphosis in the Pacific sand dollar, Dendraster excentricus. Science 225: $442-443$

Bushek, D. (1988). Settlement as a major determinant of intertidal oyster and barnacle distributions along a horizontal gradient. J. exp. mar. Biol. Ecol. 122: 1-18

Butler, A. J. (1986). Recruitment of sessile invertebrates at five sites in Gulf St. Vincent, South Australia. J. exp. mar. Biol. Ecol. 97: 13-36

Butman, C. A. (1989). Sediment-trap experiments on the importance of hydrodynamical processes in distributing settling invertebrate larvae in near-bottom waters. J. exp mar. Biol. Ecol. 134: 37-88

Caffey, H. M. (1985). Spatial and temporal variation in settlement and recruitment of intertidal barnacles. Ecol Monogr. 55: 313-332

Cameron, R. A. (1986). Introduction to the invertebrate larval biology workshop: a brief background. Bull. mar. Sci. 39 $145-161$

Cameron, R. A., Hinegardner, R. (1974). Initiation of metamorphosis in laboratory cultured sea urchins. Biol. Bull. 146: $335-342$

Cameron, R. A., Schroeter, S. C. (1980). Sea urchin recruitment: effect of substrate selection on juvenile distribution. Mar. Ecol. Prog. Ser. 2: 243-247

Cantillana, P., Inestrosa, N. C. (1993). Presence of an heparinbinding (fibroblast) growth factor in Concholepas concholepas Bruguière (Mollusca; Gastropoda; Muricidae). J exp. mar. Biol. Ecol. (in press)

Carleton, J. H., Sammarco, P. W. (1987). Effects of substratum irregularity on success of coral settlement: quantification by comparative geomorphological techniques. Bull. mar. Sci. 40: 85-98

Caswell, H. (1978). Predator-mediated coexistence: a nonequilibrium model. A.m. Nat. 112: 127-154

Chabot, R., Bourget, E. (1988). Influence of substratum heterogeneity and settled barnacle density on the settlement of cypris Larvae. Mar. Biol. 97: 45-56

Connell, J. H. (1985). The consequences of variation in initial settlement vs. post-settlement mortality in rocky intertidal communities. J. exp. mar. Biol. Ecol. 93: 11-45

Coon, S. L., Bonar, D. B., Weiner, R. M. (1985). Induction of settlement and metamorphosis of the Pacific oyster, Crassostrea gigas (Thunberg), by L-DOPA and catecholamines. J. exp. mar. Biol Ecol. 94: 211-221

Coon, S. L., Fitt, W. K., Bonar, D. B. (1990a). Competence and delay of metamorphosis in the Pacific oyster Crassostrea gigas. Mar Biol. 106: 379-387

Coon, S. L., Walch, M., Fitt, W. K., Weiner, R. M., Bonar, D. B. (1990b). Ammonia induces settlement behavior in oyster larvae. Biol. Bull. 179: 297-303

Cowden, C., Young, C. M., Chia, F.-S. (1984). Differential predation on marine invertebrate larvae by two benthic predators. Mar. Ecol. Prog. Ser. 14: 145-149

Crisp, D. J. (1955). The behaviour of barnacle cyprids in relation to water movement over a surface. J. exp. Biol. 32 $569-590$

Crisp, D. J. (1961). Territorial behaviour in barnacle settle. ment. J. exp. Biol. 38: 429-446

Crisp, D. J., Barnes, H. (1954). The orientation and distribution of barnacles at settlement with particular reference to surface contour. J. Anim. Ecol. 23: 142-162

Crisp, D. J, Ritz, D. A. (1973). Responses of cirripede larvae to light. I. Experiments with white light. Mar. Biol. 23: $327-335$

Davis, A. R. (1987). Variation in recruitment of the subtidal colonial ascidian Podoclavella cylindrica (Quoy \& Gaimard): the role of substratum choice and early survival. J. exp mar. Biol. Ecol. 106: 57-71

Davis, A. R. (1988). Effects of variation in initial settlement on distribution and abundance of Podoclavella moluccensis Sluiter. J. exp. mar. Biol. Ecol. 117: 157-167

Davis, A. R. (1989). Temperature correlates with the daily release of larvae and their settlement in a temperate Australian ascidian. In: Ryland, J. S., Tyler, P. A. (eds.) Reproduction, genetics and distributions of marine organisms. 23rd European Marine Biology Symposium. Olsen \& Olsen, Fredensborg, p. 61-65

Davis, A. R., Butler, A. J., Alten.a, I. (1991). Settlement behaviour of ascidian larvae: preliminary evidence for inhibition by sponge allelochemicals. Mar. Ecol. Prog. Ser. 72: $117-123$

Davis, A. R., Target, N. M., McConnell, O. J., Young, C. M. (1989). Epibiosis of marine algae and benthic invertebrates: natural products, chemistry and other mechanisms inhibiting settlement and overgrowth. Bioorg. mar. Chem. 3: $85-114$

Davis, A. R., Wright, A. E. (1990). Inhibition of larval settlement by natural products from the ascidian, Eudistoma ofivaceum (Van Name). J. chem. Ecol. 16: 1349-1357

Dayton, P. K. (1971). Competition, disturbance and community organization: the provision and subsequent utilization of space in a rocky intertidal community. Ecol. Monogr. 41: $351-389$

Denley, E. J., Underwood, A. J. (1979). Experiments on factors influencing settlement, survival, and growth of two species of barnacles in New South Wales. J. exp. mar. Biol. Ecol. 36: 269-293

Fairweather, P. G. (1988). Consequences of supply-side ecology: manipulating the recruitment of intertidal barnacles affects the intensity of predation upon them. Biol. Bull. 175: 349-354

Fenaux, L., Pedrotti, M. L. (1988). Metamorphose des larves d'echinides en plein eau. P. S. Z. N. I: Mar. Ecol 9: 93-107

Fitt, W. K., Coon, S. L., Walch, M., Weiner, R. M., Colwell, R. R. Bonat, D. B. (1990). Settlement behavior and metamorphosis of oyster larvae (Crassostrea gigas) in response to bacterial supernatants. Mar. Biol. 106: 389-394

Frogner, K. J (1980). Variable developmental period: intraspecific competition models with conditional age-specific maturity and mortality schedules. Ecology 61: 1099-1106

Gaines, S., Brown, S., Roughgarden, J. (1985). Spatial variation in larval concentrations as a cause of spatial variation in settlement for the barnacle, Balanus glandula. Oecologia 67: 267-272

Gaines, S., Roughgarden, J. (1985). Larval settlement rate: a 
leading determinant of structure in an ecological community of the marine intertidal zone. Proc. natl Acad. Sci. U.S.A. 82: $3707-3711$

Gaines, S., Roughgarden, J. (1987). Fish in offshore kelp forests affect recruitment to intertidal barnacle populations. Science 235: 479-481

Garnick. E. (1978). Behavioral ecology of Strongylocentrotus droebachiensis (Müller) (Echinodermata: Echinoidea). Aggregating behavior and chemotaxis. Oecologia 37 . $77-84$

Grant, A., Williamson, P. (1985). Settlement-timing hypothesis: a critique. Mar. Ecol. Prog. Ser. 23: 193-196

Grosberg, R. K. (1982). Intertidal zonation of barnacles: the influence of planktonic zonation of larvae on vertical distribution of adults. Ecology 63: 894-899

Hadfield, M. G. (1963). The biology of nudibranch larvae. Oikos 14: 85-95

Hadfield, M. G. (1984). Settlement requirement of molluscan larvae: new data on chemical and genetic roles. Aquaculture 39: $283-298$

Hadfield, M. G. (1986). Settlement and recruitment of marine invertebrates: a perspective and some proposals. Bull. mar. Sci. 39: 418-425

Hadfield, M. G., Pennington, J. T. (1990). Nature of the metamorphic signal and its internal transduction in larvae of the nudibranch Phestilla sibogae. Bull. Mar. Sci. 46: $455-464$

Hannan, C. A. (1984). Planktonic larvae may act like passive particles in turbulent near-bottom flows. Limnol. Oceanogr. 29: 1108-1116

Harrold, C., Lisin, S., Light, K. H., Tudor, S. (1991). Isolating settlement from recruitment of sea urchins. J. exp. mar. Biol. Ecol. 147: 81-94

Hart, M. W. Scheibling, R. E. (1988). Heat waves, baby booms, and the destruction of kelp beds by sea urchins. Mar. Biol. 99: 167-176

Hawkins, S. J., Hartnoll, R. G. (1982). Settlement patterns of Semibalanus balanoides (L.) in the Isle of Man (1977-1981). J. exp. mar. Biol. Ecol. 62: 271-283

Hidu, H., William, G. V., Veitch, F. P. (1978). Gregarious setting in European and American oysters-response to surface chemistry versus waterborne pheromones. Proc. natl. Shellfish. Ass. 68: 11-16

Highsmith, R. C. (1982). Induced settlement and metamorphosis of sand dollar (Dendraster excentricus) larvae in predator-free sites: adult sand dollar beds. Ecology 63 329-337

Highsmith, R. C., Emlet, R. B. (1986). Delayed metamorphosis: effect on growth and survival of juvenile sand dollars (Echinoidea: Clypeasteroida). Bull. mar. Sci. 39: $347-361$

Hirata, K. Y., Hadfield, M. G. (1986). The role of choline in metamorphic induction of Phestilla (Gastropoda: Nudibranchia). Comp. Biochem. Physiol. 84C: 15-21

Holm, E. R. (1990). Effects of density-dependent mortality on the relationship between recruitment and larval settlement. Mar. Ecol. Prog. Ser. 60: 141-146

Hughes, T. P. (1990). Recruitment limitation, mortality, and population regulation in open systems: a case study. Ecology 71: 12-20

Hurlbut, C. J. (1991). Community recruitment: settlement and juvenile survival of seven co-occurring species of sessile marine invertebrates. Mar. Biol. 109: 507-515

Inestrosa, N. C., Campos, E. O., González, M. A. (1992) Inducción de metamorfosis en larvas de Concholepas concholepas por el ión potasio. Boln Red Latinoam. Acuicult. 6: $16-19$
Inestrosa, N. C., González, M., Campos, E. O. (1993). Molecular changes induced by metamorphosis in larvae of the prosobranch Concholepas concholepas (Mollusca; Gastropoda; Muricidae). J. exp. mar. Biol. Ecol. (in press) lnestrosa, N. C., González, R., González, M. A., Perelman, A., Sánchez, J. P., Koenig, C., Brandan, E. (1988). Investigaciones biotecnológicas en larvas de 'Loco', Concholepas concholepas (Bruguière, 1789) (Gastropoda: Muricidae). Biol. Pesq. Chile 17.73-94

Inestrosa, N. C., Labarca, R., Perelman, A., Campos, E. O. Araneda, R., González, M., Brandan, E., Sánchez, J. P., González, R. (1990). Biotechnological aspects in 'Loco' larvae. Arch. Biol. Med. Exp. 23: 179-186

Jablonski, D., Lutz, R. A. (1983). Larval ecology of marine benthic invertebrates: paleobiological implications. Biol. Rev. 58: 21-89

Jackson, G. A. (1986). Interaction of physical and biological processes in the settlement of planktonic larvae. Bull. mar. Sci. 39: 202-212

Jensen, R. A., Morse, D. E. (1984). Intraspecific facilitation of larval recruitment: gregarious settlement of the poly. chaete Phragmatopoma californica (Fewkes). J. exp. mar. Biol. Ecol. 83: 107-126

Jensen, R. A., Morse, D. E. (1990). Chemically induced metamorphosis of polychaete larvae in both the laboratory and the ocean environment. J. chem. Ecol. 16: 911-930

Johnson, C. R., Muir, D. G., Reysenbach, A. L. (1991a). Characteristic bacteria associated with surfaces of coralline algae: a hypothesis for bacterial induction of marine invertebrate larvae. Mar. Ecol. Prog. Ser. 74: 281-294

Johnson, C. R., Sutton, D. C., Olson, R. R., Giddins, R. (1991b). Settlement of crown-of-thorns starfish: role of bacteria on surfaces of coralline algae and a hypothesis for deepwater recruitment. Mar. Ecol. Prog. Ser. 71: 143-162

Karlson, R. H., Levitan, D. R. (1990). Recruitment-limitation in open populations of Diadema antillarum: an evaluation. Oecologia 82: 40-44

Kato, T., Kumanireng, A. S., Ichinose, I., Kitahara, Y., Kakinuma, Y., Nishihira, M., Kato, M. (1975). Active components of Sargassum tortile affecting the settlement of swimming larvae of Coryne uchidai. Experientia 31: $433-434$

Keough, M. J. (1983). Patterns of recruitment of sessile invertebrates in two subtidal habitats. J. exp. mar. Biol. Ecol. 66 : $213-245$

Keough, M. J. (1984). Dynamics of the epifauna of the bivalve Pinna bicolor interactions among recruitment, predation, and competition. Ecology 65: 677-688

Keough, M. J. (1986). The distribution of a bryozoan on seagrass blades: settlement, growth, and mortality. Ecology 67: 846-857

Keough, M. J., Downes, B. J (1982). Recruitment of marine invertebrates: the role of active larval choices and early mortality. Oecologia 54:348-352

Kirchman, D., Graham, S., Reish, D., Mitchell, R. (1982). Bacteria induce settlement and metamorphosis of Janua (Dexiospira) brasiliensis Grube (Polychaeta: Spirorbidae). J. exp. mar. Biol. Ecol. 56: 153-163

Knight-Jones, E. W. (1953). Laboratory experiments on gregariousness during setting in Balanus balanoides and other barnacles. J. exp. Biol. 30: 584-599

Kuffler, S. W., Nicholls, J. G., Martin, A. R. (1984). From Neuron to brain. Sinauer Associates, Sunderland, MA

Le Tourneux, F., Bourget, E. (1988). Importance of physical and biological settlement cues used at different spatial scales by the larvae of Semibalanus balanoides. Mar. Biol. 97: $57-66$ 
Levantine, P. L., Bonar, D. B. (1986). Metamorphosis of llyanassa obsoleta: natural and artificial inducers. Am. Zool. 26: 14 A (Abstract)

Lewin, R. (1986). Supply-side ecology. Science 234: 25-27

Lewis, J. R., Bowman, R. S., Kendall, M. A., Williamson, P. (1982). Some geographical components in population dynamics: possibilities and realities in some littoral species. Neth. J. Sea Res. 16: 18-28

Loosanoff, V. L. (1964). Variations in time and intensity of setting of the starfish, Asterias forbesi, in Long Island Sound during a twenty-five-year period. Biol. Bull. 126: 423-439

Maki, J. S., Rittschof, D., Costlow, J. D., Mitchell, R. (1988). Inhibition of attachment of larval barnacles, Balanus amphitrite, by bacterial surface films. Mar. Biol. 97: 199-206

Maki, J. S., Rittschof, D., Schmidt, A. R., Snyder, A. G., Mitchell, R. (1989). Factors controlling attachment of bryozoan larvae: a comparison of bacterial films and unfilmed surfaces. Biol. Bull. 177: 295-302

May, R. M., Oster, G. F. (1976). Bifurcations and dynamic complexity in simple ecological models. Am. Nat. 110. $573-599$

McGuinness, K. A., Davis, A. R. (1989). Analysis and interpretation of the recruit-settler relationship. J. exp. mar. Biol. Ecol. 134: 197-202

McShane, P. E. (1991). Density-dependent mortality of recruits of the abalone Haliotis rubra (Mollusca: Gastropoda). Mar. Biol. 110: 385-389

Menge, B. A. (1976). Organization of the New England rocky intertidal community: role of predation, competition and environmental heterogeneity. Ecol. Monogr. 46: $355-393$

Menge, B. A., Sutherland, J. P. (1976). Species diversity gradients: synthesis of the roles of predation, competition, and temporal heterogeneity. Am. Nat. 110:351-369

Menge, B. A., Sutherland, J. P. (1987). Community regulation: variation in disturbance, competition, and predation in relation to environmental stress and recruitment. Am. Nat. 130: $730-757$

Mileikovsky, S. A. (1974). On predation of pelagic larvae and early juveniles of marine bottom invertebrates by adult benthic invertebrates and their passing alive through their predators. Mar. Biol. 26: 303-311

Minchinton, T E., Scheibling, R. E. (1991). The influence of larval supply and settlement on the population structure of barnacles. Ecology 72: 1867-1879

Morse, A. N. C. (1991). How do planktonic larvae know where to settle?. Am. Scient. 79: 154-167

Morse, A. N. C., Froyd, C. A., Morse, D. E. (1984). Molecules from cyanobacteria and red algae that induce larval settlement and metamorphosis in the mollusc Haliotis rufes. cens. Mar. Biol. 81. 293-298

Morse, A. N. C., Morse, D. E. (1984). Recruitment and metamorphosis of Haliotis larvae induced by molecules uniquely available at the surfaces of crustose red algae. J. exp. mar Biol. Ecol. 75: 191-215

Morse, D. E. (1990). Recent progress in larval settlement and metamorphosis: closing the gaps between molecular biology and ecology. Bull. mar. Sci. 46: 465-483

Morse, D. E., Helen, H., Hooker, N., Baloun, A., Young, G. (1980). GABA induces behavioral and developmental metamorphosis in planktonic molluscan larvae. Federation Proc. 39: 3237-3241.

Morse, D. E., Hooker, N., Duncan, H., Jensen, L. (1979). g-aminobutyric acid, a neurotransmitter, induces planktonic abalone larvae to settle and begin metamorphosis. Science 204: 407-410

Ojeda, F. P., Dearborn, J. H. (1991). Feeding ecology of ben- thic mobile predators: experimental analyses of their influence in rocky subtidal communities of the Gulf of Maine. J. exp. mar. Biol. Ecol. 149: 13-44

Paine, R. T. (1963). Ecology of the brachiopod Glottidia pyramidata. Ecol. Monogr. 33: 187-213

Paine, R. T. (1974). Intertidal community structure: experimental studies on the relationship between a dominant competitor and its principal prey. Oecologia 15: 93-120

Paine, R. T. (1984). Ecological determinism in the competition for space. Ecology 65: 1339-1348

Pawlik, J. R. (1986). Chemical induction of larval settlement and metamorphosis in the reef-building tube worm Phragmatopoma californica (Sabellariidae: Polychaeta). Mar. Biol. 91: 59-68

Pawlik, J. R. (1990). Natural and artificial induction of metamorphosis of Phragmatopoma lapidosa californica (Polychaeta: Sabellariidae), with a critical look at the effects of bioactive compounds on marine invertebrate larvae. Bull. mar. Sci. 46:512-536

Pawlik, J. R., Butman, Ch. A., Starczak, V. R. (1991). Hydrodynamic facilitation of gregarious settlement of a reef-building tube worm. Science 251: 421-424

Pawlik, J. R., Hadfield, M. G. (1990). A symposium on chemical factors that influence the settlement and metamorphosis of marine invertebrate larvae: introduction and perspective. Bull. mar. Sci. 46:450-454

Pearce, C. M., Scheibling, R. E. (1990a). Induction of metamorphosis of larvae of the green sea urchin, Strongylocentrotus droebachiensis, by coralline red algae. Biol. Bull. 179: 304-311

Pearce, C. M., Scheibling, R. E. (1990b). Induction of settlement and metamorphosis in the sand dollar Echinarachnius parma: evidence for an adult-associated factor. Mar. Biol. 107: 363-369

Pearce, C. M. Scheibling, R. E. (1991). Effect of macroalgae, microbial films, and conspecifics on the induction of metamorphosis of the green sea urchin Strongylocentrotus droebachiensis (Müller). J. exp. mar Biol. Ecol. 147: $147-162$

Pearse, J. S., Arch, S. W. (1969). The aggregation behavior of Diadema (Echinodermata: Echinoidea). Micronesica 51: $166-171$

Pechenik, J. A., Heyman, W. D. (1987). Using KCl to determine size at competence for larvae of the marine gastropod Crepidula fornicata (L.) J exp. mar. Biol. Ecol. 112: $27-38$

Pennington, J. T., Hadfield, M. G. (1989). Larvae of a nudibranch mollusc (Phestilla sibogae) metamorphose when exposed to common organic solvents. Biol. Bull. 177: 350-355

Raimondi, P. T. (1988). Settlement cues and determination of the vertical limit of an intertidal barnacle. Ecology 69 : $400-407$

Raimondi, P. T (1991). Settlement behavior of Chthamalus anisopoma larvae largely determines the adult distribution. Oecologia 85: 349-360

Rittschof, D., Maki, J., Mitchell, R., Costlow, J D. (1986). Ion and neuropharmacological studies of barnacle settlement. Neth. J. Sea Res. 20: 269-275

Roberts, D., Rittschof, D., Holm, E., Schmidt, A. R. (1991\} Factors influencing initial larval settlement: temporal, spatial and surface molecular components. J. exp. mar Biol Ecol. 150: 203-211

Rodríguez, S. R., Ojeda, F. P., Inestrosa, N. C. (1992). Inductores químicos del asentamiento de invertebrados marinos bentónicos: importancia y necesidad de su estudio en Chile. Revta. Chil. Hist nat 65: 297-310 
Roegner, G. C. (1991). Temporal analysis of the relationship between settlers and early recruits of the oyster Crassostrea virginica (Gmelin). J. exp. mar. Biol. Ecol. 151: 57-69

Roughgarden, J., Iwasa, Y., Baxter, C. (1985). Demographic theory for an open marine population with space-limited recruitment. Ecology 66: 54-67

Roughgarden, J., Pennington, J. T., Stoner, D., Alexander, S., Miller, K. (1991). Collisions of upwelling fronts with the intertidal zone: the cause of recruitment pulses in barnacle populations of central California. Acta oecol. 12: 35-51

Rowley, R. J. (1989). Settlement and recruitment of sea urchins (Strongylocentrotus spp.) in a sea-urchin barren ground and a kelp bed: are populations regulated by settlement or post-settlement processes? Mar. Biol. 100 $485-494$

Russo, A. R. (1979). Dispersion and food differences between two populations of the sea urchin Strongylocentrotus franciscanus. J. Biogeogr. 6: 407-414

Sebens, K. P. (1983a). The larval and juvenile ecology of the temperate octocoral Alcyonium siderium Verril. I. Substratum selection by benthic larvae. J. exp. mar. Biol. Ecol. 71: 73-89

Sebens, K. P. (1983b). Settlement and metamorphosis of a temperate soft-coral larva (Alcyonium siderium Verril): induction by crustose algae. Biol. Bull. 165: 286-304

Seki, T., Kan-no, H. (1981). Induced settlement of the japanese abalone, Haliotis discus hannai, veliger by the mucus of the juvenile and adult abalones. Bull. Tohoku reg. Fish. Res. Lab. 43: 29-36

Slattery, M. (1992). Larval settlement and juvenile survival in the red abalone (Haliotis rufescens): an examination of inductive cues and substrate selection. Aquaculture 102: $143-153$

Steneck, R. S. (1982). A limpet-coralline alga association: adaptations and defenses between a selective herbivore and its prey. Ecology 63: 507-522

Sutherland, J. P. (1990). Recruitment regulates demographic variation in a tropical intertidal barnacle. Ecology 71. 955-972

Sutherland, J. P., Ortega, S. (1986). Competition conditional on recruitment and temporary escape from predators on a tropical rocky shore. J. exp. mar Biol. Ecol. 95: $155-166$

Tegner, M. J., Dayton, P. K. (1981). Population structure, recruitment and mortality of two sea urchins (Strongylocentrotus franciscanus and S. purpuratus) in a kelp forest. Mar. Ecol. Prog. Ser. 5: 255-268

Thorson, G. (1950). Reproductive and larval ecology of marine bottom invertebrates. Biol. Rev. 25: 1-45

Todd, C. D. (1985). Settlement-timing hypothesis: reply to Grant and Williamson. Mar. Ecol. Prog. Ser. 23: 197-202

Todd, C. D., Bentley, M. G., Havenhand, J. N. (1991). Larval metamorphosis of the opisthobranch mollusc Adalaria proxima (Gastropoda: Nudibranchia): the effects of choline and elevated potassium ion concentration. J. mar. biol. Ass. U.K. 71: 53-72
Trapido-Rosenthal, H. G., Morse, D. E. (1986a). Regulation of receptor-mediated settlement and metamorphosis in larvae of a gastropod mollusc (Haliotis rufescens). Bull. mar Sci. 39: 383-392

Trapido-Rosenthal, H. G., Morse, D. E. (1986b). Availability of chemosensory receptors is down-regulated by habituation of larvae to a morphogenetic signal. Proc. natl. Acad. Sci. U.S.A. 83: $7658-7662$

Underwood, A. J. (1972). Spawning, larval development and settlement behaviour of Gibbula cineraria (L.) (Gastropoda: Prosobranchia) with a reappraisal of torsion in gastropods. Mar. Biol. 17: 341-349

Underwood, A. J. (1979). The ecology of intertidal gastropods Adv. mar. Biol. 16: 111-210

Underwood, A. J., Denley, E. J. (1984). Paradigms, explanations, and generalizations in models for the structure of intertidal communities on rocky shores. In: Strong, D. R., Simberloff, D., Abele, L. G., Thistle, A. B. (eds.) Ecological communities: conceptual issues and the evidence. Princeton University Press, Princeton, p. 151-180

Underwood, A. J., Fairweather, P. G. (1989). Supply-side ecology and benthic marine assemblages. Trends Ecol. Evol. 4 : $16-20$

Victor, B. C. (1983). Recruitment and population dynamics of a coral reef fish. Science $219: 419-420$

Watanabe, J. M. (1984). The influence of recruitment, competition, and benthic predation on spatial distributions of three species of kelp forest gastropods (Trochidae: Tegula). Ecology 65: 920-936

Watanabe, J. M., Harrold, C. (1991). Destructive grazing by sea urchins Strongylocentrotus spp. in a central California kelp forest: potential roles of recruitment, depth, and predation. Mar. Ecol. Prog. Ser. 71: 125-141

Wethey, D. S. (1986). Ranking of settlement cues by barnacle larvae: influence of surface contour. Bull. mar. Sci. 39: $393-400$

Woodin, S. A. (1991). Recruitment of infauna: positive or negative cues? Am. Zool 31: 797-807

Yool, A. J., Grau, S. M., Hadfield, M. G., Jensen, R. A., Markell, D. A., Morse, D. E. (1986). Excess potassium induces larval metamorphosis in four marine invertebrate species. Biol. Bull. 170: 255-266

Yoshioka, P. M. (1982). Role of planktonic and benthic factors in the population dynamics of the bryozoan Membranipora membranacea. Ecology 63: 457-468

Young, C. M. (1987). Novelty of supply-side ecology. Science 235: 415-416

Young, C. M., Chia, F. -S. (1982). Factors controlling spatial distribution of the sea cucumber Psolus chitonoides: settling and post-settling behavior. Mar. Biol. 69: $195-205$

Zimmerman, K. M., Pechenik, J. A. (1991). How do temperature and salinity affect relative rates of growth, morphological differentiation, and time to metamorphic competence in larvae of the marine gastropod Crepidula plana? Biol. Bull. 180: 372-386

Manuscript first received: July 24, 1992

Revised version accepted: March 23, 1993 